\title{
Ter begeleiding
}

Gedurende die eerste week van Desember 1957 het daar aan die Universiteit van Pretoria 'n kongres van Ou-Testamentici uit verskillende dele van ons land en bestaande uit lede van al drie die Afrikaanse kerke, plaasgevind. Die kongres het oorgegaan tot die stigting van 'n OuTestamentiese Werkgemeenskap, wat hom ten doel stel die bevordering van die Ou-Testamentiese wetenskap in Suid-Afrika. Die voorneme is dat die werkgemeenskap jaarliks sal vergader. Hopelik sal die tweede vergadering gedurende die eerste week van Februarie 1959 te Potchefstroom gehou word.

Aan die einde van die kongres is die wens uitgespreek dat die verskillende voordragte en mededelings gepubliseer moet word. Die redaksie van die Hervormde Teologiese Studies was so vriendelik om hierdie uitgawe tot ons beskikking te stel vir hierdie doel. Namens die OuTestamentiese Werkgemeenskap wil ek my hartlike dank uitspreek teenoor die redaksie vir hierdie vriendelike daad. Daarsonder sou daar nie voldoen kon word nie aan die versoek van die kongres. Danksy hierdie welmenende gebaar van die redaksie kan die eerste voordragte op die eerste kongres van die werkgemeenskap hiermee aan 'n breër kring aangebied word. Ons vertrou dat die gereelde lesers van die Hervormde Teologiese Studiekring veel genoeë sal ondervind by die lees daarvan.

Univ. van Pretoria,

9 Sept. 1958.
A. H. VAN ZYL

(Alg. Sekr. O. T. Werkgemeenskap) 